DOI: https://doi.org/10.3126/njdrs.v17i0.34982

\title{
Conventional Farming Practices around Kathmandu Valley: An Appraisal
}

\author{
Suman Kharel, PhD* and Deepak Marahatta** \\ *Lecturer at Central Department of Rural Development \\ **PhD Scholar at Central Department of Rural Development \\ Tribhuvan University, Kirtipur, Kathmandu \\ Email for correspondence: suman.kharel@cdrd.tu.edu.np and deman19@gmail.com
}

\begin{abstract}
Conventional farming is a new area of research in developing countries. It is rooted in industrial agriculture and focuses on production as heavily. It demands a high amount of chemical fertilizers. The research follows a case study under the interpretive paradigm using multiple sources of evidence such as interviews, observations, and surveys of the literature. Usual to most conventional practices, the local inbreeds of crops are replaced by high yielding varieties of crops. One of the main advantages of conventional farming is the application of a higher amount of agricultural inputs. The study has shown that the availability of transport made it easy to reach products to the market and has contributed to increasing the income of the farmers. Inadequate knowledge of the use of fertilizers and pesticides results in the origins of new diseases in crops is a major challenge of conventional farming. This research concludes that commercial organic farming can be an alternative to conventional farming. The finding shows the need for agricultural training and capacity building of farmers and also the need to provide subsidies so that farming will be more lucrative.
\end{abstract}

Key words: Conventional farming, chemical fertilizers, labor, gender role, knowledge, perception, subsidies

\section{Introduction}

Conventional farming is defined as crop production practice applying petroleum-based chemical fertilizer, a chemical pesticide, and growth-stimulating chemicals (MoAC, 2008). In conventional farming farmers generally grow three or more crops in a year to maximize the profit out of the land (Dahal, 2000). Conventional farming increase per area food production, but deplete natural resources and degrade both crops and environmental quality (Zinati, 2002). Before the green revolution, Nepali farmers followed the traditional farming method where farmers only used organic manure in the field (MoAC, 2008). When the green revolution entered Nepal after the 1960s, it promoted Nepali farmers to follow conventional farming (Shrestha, 2010). The heavy use of chemical fertilizers then started which in turn increased the productivity of land and increases production. The farmers got higher economic benefits than traditional farming methods. However, land degradation and other negative aspect have largely been ignored and many other associated problems have emerged. But there is a lack of adequate knowledge, skill, technology, and entrepreneurship in conventional farming among 
farmers (Deshar, 2013). Consequently, the haphazard application of chemical fertilizers and pesticides has created several impacts on agriculture (Baker \& Gyawali, 1994).

Agriculture is the major sector of the Nepalese economy that provides employment opportunities to 66 percent of the total population and contributes about 13 percent of the total foreign trade of the country (Department of Agriculture, 2013). The contribution of the agriculture sector to GDP is 27.59 percent and the growth rate of the agriculture sector is 2.7 percent in the FY 2017/18 which was 3.2 percent during the past two decades (MoF, 2019). Nepal was one of the major exporters of rice in South Asia before 1980, but after the rise of Green Technology worldwide it could not compete with other nations, as a result, it becomes the rice and food grain importer (Blaikie et. al. 1980; Sapkota, 2011). Over the last five decades, population growth has increased and put pressure on productivity. One result of this pressure has been a decrease in the average size of land holdings from 1.1 hectares to 0.7 hectares (Investment Board Nepal, 2019).

The report shows Nepal imported agricultural products worth $\$ 1.298$ billion in the fiscal year 2013/14, its exports amounted to only \$ 268.91 million (IBN, 2019). After the 1980s, farming is gradually changing to commercial however is limited to a few populations. Due to the impact of globalization, farmers started using hybrid seeds, chemical fertilizers, and pesticides. This has increased the production of crops in their hand however declined the production of local seeds on the other (Dahal, 2000). The major stakeholders of agriculture - the people, and the government - both are facing the problem of making agriculture a dependable profession and a reliable economic sector of the country (Dahal, 2000). Pasa (2017) also argues that Nepal is facing central challenge for shifting traditional subsistence farming into modern farming and adaptation of traditional technology into modern technology. The government's 2012 Agriculture Development Strategy Assessment Report estimated 200,000 youth, especially from rural areas, migrated abroad for employment in 2010, leaving mostly women, children, and the elderly behind at home. Twenty-Year Agricultural Development Strategy has been implemented since FY 2016/17 to make the country self-dependent on food by the year 2035 through increasing agricultural production and productivity. The strategy also prioritizes the commercial agriculture system and conserving of the sustainable environment (MoF, 2019).

The benefits and challenges of conventional farming arediscussed over time. One of the major benefits of conventional farming is it increases food production and offers an increased yield (Zinati, 2002; Pacini, 2003) due to the application of anamount of agricultural high inputs. On the other hand, intensive use of agro-chemical input and farm practices led to environmental degradation (Scialabba, 2000), deplete natural resources, and degrade both crop quality and environmental quality (Zinati, 2002). In the context of Nepal, conventional agriculture-focused merely on yield rising to meet the growing food needs of the increasing population and paid little concern to a sustainable use of locally available both natural and human resources (Pokhrel \& Pant, 2009).

\section{Objectives}

- To examine socio-demographic characteristics of the participants.

- To explore knowledge and perceptions of the farmers on conventional farming.

- To appraise socio-economic benefits and challenges of conventional farming. 


\section{Methods and Materials}

This study is applied interpretive research paradigm that is useful in analyzing human experience because it sees the world as constructed, interpreted, and experienced by people in their interactions with each other and with wider social systems (Tuli, 2010). Accordingly, perceptions and lived experiences of the local farmers practicing conventional farming in rural setting have been appraised. Under the interpretive paradigm, the multi site case study method is used in which unit of analysis six farmers (cases) were belonging to five different geographical locations (i.e Bhimdunga, Ramkot, Mulpani, Lubu, and Lamatar) of Kathmandu Valley. These five locations are situated away from the core city area where conventional farming is the main livelihood of the people. In total six farmers; are selected for this study through purposive sampling. Farmers are selected based on landholding size ${ }^{1}$ and years of involvement in conventional farming ${ }^{2}$. To identify the farmers, the researcher visited the place several times and collect the list of farmers with support from the local informant. After taking pre-consent from the informant's family, the interview scheduled is planned. For the interview, a semistructured questionnaire is developed and an interview is recorded and a field note is maintained. The researcher has directly observed the actual field activities. For ethical purposes,a pseudonym is given to each respondent and the same pseudonym is used throughout the discussion section. Table 1 gives information about the sample informants.

Table 1. Social Demographic Information of the Participants

\begin{tabular}{llllll}
\hline $\begin{array}{l}\text { Participants } \\
\text { (Pseudonym) }\end{array}$ & Location & Sex & Age & $\begin{array}{l}\text { Land Size }^{1} \\
\text { (Approx) }\end{array}$ & $\begin{array}{l}\text { Years of } \\
\text { Farming }\end{array}$ \\
Ram & Mulpani & Male & 72 & 7 Ropani & $50+$ \\
Manoj & Mulpani & Male & 55 & 11.5 Ropani & $30+$ \\
Ganga & Bhimdhunga & Female & 81 & 9 Ropani & $50+$ \\
Amrit & Ramkot & Male & 48 & 5 Ropani & $25+$ \\
Balu & Lamatar & Male & 33 & 8 Ropani & $10+$ \\
Sita & Lubu & Female & 69 & 6 Ropani & $40+$ \\
\hline
\end{tabular}

These six informants have more than 5 ropani lands. Out of six informants, two informants are female. These informants have been engaging in farming for more than 10 years. The study has examined conventional farming form the point of views of farmers knowledge and perception regarding the chemical fertilizer and pesticide, use of compost, use of high yielding varieties of seeds, farmers knowledge on Hybrid seeds, gender roles in farming, labor input, marketing system, income and finally explore the farmers' perception of conventional farming.

\section{Results: Use of Chemical Fertilizers and Pesticides}

The use of fertilizers and pesticides are very common in conventional farming. All informants have been using fertilizers and pesticides. The use of pesticides and fertilizers is widespread in commercial production areas due to conventional agriculture-based market and infrastructure development (Pokhrel \& Pant, 2009). During an interview, an informant (Ram) said that he has been

1 Farmers who have their own land between 5 ropani to 15 ropani (The value of land size is based on interview period, 2016)

2 Engage in more than 10 years in farming in same land size

Nepalese Journal of Development and Rural Studies, Volume 17 
using fertilizers and pesticides for a long time to increase the production of the crops and to protect crops from various pests and diseases. He has a separate storeroom for fertilizers and pesticides. He often buys fertilizers and pesticides from Rakshaul every two years. He stored these chemicals in a room with the same form as it has brought from Raksaul. Other five informants said they buy these fertilizers and pesticides from the local market. All informants said they use chemical fertilizers to increase the yields. One research in Nepal shows the increasing number of family size creates more pressure on land and to meet the demands, excessive fertilizers and pesticides are used (Jha, 2000). Another research shows production can be increased by 50 percent in Nepal through the application of fertilizer (Bhatt, 2000). The informants have a similar opinion regarding the use of pesticides. One of the informant Manoj said that;

We used to see very fewer pests in the past so we used to use natural pests such as a mixture of cow-dung and titepati ${ }^{3}$, however, many new diseases are emerging and harming the crops so there is need of using of these pesticides now as natural pesticides are not sufficient and not available".

Gita also has a similar understanding of the use of pesticides. She said that "there were no any diseases observed in the past however, many diseases are seen now and we could not figure out what these diseases are?" She further added that "if we do not use pesticide then we cannot kill pests and if pests do not die then we do not get yields". Research shows, with the increasing commercialization of crop cultivation and the easy availability of quick-acting chemical pesticides, most farmers are adopting modern pesticides in place of their traditional practices and local alternatives (Adhikari, 2008).

Regarding the ways of using these chemical fertilizers two informants Manoj and Balu have taken the training. However, they said that the training is not sufficient to understand various aspects of farming. The other four informants have not taken any training on farming. They purchase fertilizers and pesticides in two ways: either with the feedbacks of neighbors or from the prescription of the shopkeepers. This shows farmers are conventionally using these fertilizers and pesticides. One of the informant's Ram said he is using the same fertilizers in a different interval of time. The perception of Ganga, Amrit, and Sita is also similar. These informants do not have access to agriculture experts and agricultural centers but these chemical fertilizers are easily available in the market so farmers do not have any problem getting access to it. Informant Amrit said,“an increasing number of new pests every year consequently increases the demand for pesticides and sometimes farmers do not understand which pesticides need to use for which pests".

\section{Use of Compost}

Compost is common in conventional farming and it contains major components for soil fertility. The residues of crops and animal dungs are used for making compost. Along with chemical fertilizers, all six informants said that they make compost and use compost in farming. All these six informants have cows. Besides, four informants Ram, Amrit, Balu, and Gita also have goats. The research shows livestock of different kinds including poultry has been a major source of organic manure for agricultural production (Singh, Karki \& Shah, 2000). After farmers harvest crops, the residue of maize, wheat, and vegetables are used to make compost either through burning or through decomposing. These informants said they have been using the compost since they know to farm. Informant Ram, Ganga and said they

3 Herbal plant bitter in taste and use for killing pests

Nepalese Journal of Development and Rural Studies, Volume 17 
only used compost before 25 years, however now they are using fertilizers along with compost. They said that amount of compost used in farming is declining in the last ten years. One informant Balu said that compost is composed of various soil nutrients such as nitrogen, phosphorous, and potassium and it helps to keep a balance of all soil nutrients. Informant Manoj believes that compost is a good source of soil nutrients and said that it is better to reduce the number of chemical fertilizers so that it protects from the soil being degraded. Slow-release of compost substances enables the plant to absorb more nutrient material before it seeps into the ground (Singh, Karki \& Shah, 2000). In conventional farming, compost is also used to provide supplements nutrition for the soil.

\section{Use of Hybrid Seeds}

Hybrid seeds are commonly used in conventional farming. These hybrid seeds are easily available in the market. The common brands that are available easily in the market are used in farming. Generally, farmers change the seeds every two to three years. Research shows high yielding varieties spread more widely and more quickly than other technological innovations in the history of agriculture (Jha, 2000). Informant Manoj said, "Local seeds do not give high yields and are not available in the market so farmers do not have any other alternatives except using these hybrid seeds". Other informants also said local seeds are not easily available in the market and if available also farmers could not get the required quantity. It is due to the globalization of the seeds, which has resulted in the replacement of local seeds by introducing high-quality seeds (Nagaraj et.al., 2006). Nepal is producing 4,700,000 MT of rice, whereas the nation's requirement is 5,400,000 MT. The shortage of 700,000 - 800,000 MT of paddy can be replenished if we could increase the production by $0.50 \mathrm{MT}$ per hectare. There is a growing awareness among agriculture

The stakeholders serving hybrid vegetable seeds are gaining popularity (IBN, 2019). Informant Ram said that due to the impact of hybrid seeds, new seeds need to change every two to three years. He noticed that due to the use of these hybrid seeds, the taste of the food is changing. He believes that there is no more good smell and taste. Another informant Balu said he only uses local seeds for rice so that he can have a local taste, however, he uses hybrid seeds for Maize and wheat. Amrit believes that though local seeds are good for quality taste and health, it doesn't give higher yields. Since he has to sell maize and other crops, he uses hybrid seeds to get higher yields. He also said that due to an increase in family members there is pressure to produce more from the same land so he has to go with the hybrid seeds. Sita shared an interesting story behind using hybrid seed. She shared her story like this:

"We used to use local seeds of paddy and maize but for the regular three years the rice and maize yield has been decreased but we did not know the actual reason for decreasing their yields. We observed that the paddy was burned and there was no seed inside the maize. We get frustrated and changed the seed of paddy and maize as per the suggestion of our neighbors. The following year when we applied hybrid seeds, we did not find any problem we find more yields. Since then we are using hybrid seeds only. But we do not know what had happened with the local seeds".

Another informant Ganga doesn't use the local seeds because she believes that local seeds give lesser production than hybrid seeds. One research shows at the village level the local seeds are completely replaced by the hybrid and imported varieties, especially in cereals and vegetables (Tamang, Dhital, \& Acharya, 2011). 


\section{Lack of Adequate Knowledge}

Education helps in providing knowledge, skills, and opportunity to every individual. In agriculture, farmers need to have adequate knowledge on the use of fertilizers, pesticides, seeds, compost, water management, and crop rotation pattern. In this research, informant Manoj and Balu are university graduates, Amrit passed lowers secondary level, Ram and Ganga are literate whereas Sita is illiterate. All informants said that they learned farming through experiences by observing, participating, and listening from the seniors. During an interview, informant Ram said that he did not have formal education. However, he has received only training on the use of new technologies, fertilizers, and pesticides in agriculture. He said that that training was not sufficient for him to understand farming. Another informant Manoj claimed that farmers do not have proper knowledge on the use of hybrid seeds, pesticides, and fertilizers. He said, though he is educated, he faced challenges like finding out new diseases in crops, growth of ovule structure in the root, burning of seed, and new forms of pests. However, he could not figure out the actual reasons for such problems. He shared his own experiences as, three years ago I bought hybrid seed of maize from the market; for the first year the yield was good, but last year the yield was decreased and I do not know what will happen this year".

Informant Sita said she had never received any training or other skills-oriented indeterminateness to farming. She learned farming through experiences. She believes that if she would have received good information and training on farming she would easily face problems that arise during the farming. Informant Balu said that he knows the impact of using chemical fertilizers and pesticides on human health so he sells vegetables at least a week after spreading chemical fertilizers. Informant Amrit accepts that fertilizers and hybrid seeds are used without proper knowledge and instruction. Research shows most of the farmers involving in conventional farming in Nepal is either illiterate or semi-literate (Dahal, 2000; Deshar, 2013). In this study, two informants Balu and Manoj are more concerned about the proper use of chemical fertilizers, and the use of new agriculture tools in farming. The other four informants are less concerned about these matters. One study showed educated farmers have more knowledge of various crops and their benefits to health (Singh \& Maharjan, 2017).

\section{Labor Arrangement}

The 'Parma' system is commonly practiced in which farmers do not need to pay money, instead, they have to exchange labor which they claimcost-effective. This 'parma' system currently exists in Sita's village. She said that there is a 'Parma' system in her village and it has made farming easier and has reduced the cost of farming. However, the other five informants do not experience the 'Parma' system now. Informant Ganga said there is no 'Parma' system now so she needs to depend on wage labor for farming. She said that farming became expensive due to the increasing cost of wage labor. She said that it is difficult to get wage labor at the desired time. She said that "when I need 10 wage labor, I only get 5 to 6 wage labors. Last year I paid NRs. 850 for labor but this year I pay NRs. 1000 for one labor." Despite her two sons are involved in commercial farming she believes that the young generation of her area is not interested in agriculture. Other informants Manoj, Amrit, and Balu also have the same experience as Ganga. These informants said that farming is expensive due to increasing wage labor costs. Both Manoj and Amrit said their children do not provide any support for them in farming and are not interested in agriculture. Ram has also experienced the same with his following expressions: 
"I have two sons and four grandchildren. My grandchildren are small so they do not understand anything about farming. My two sons do not like to work in the agriculture field. I have never seen them working in the field. They neither interested in farming nor do they support me on the field".

One research study shows that the young generation is not interested in conventional farming. Tamang et al., (2011, p. 6) write:

"Now a day's particularly youth are distracting from the agriculture field. They think once they have some academic degree, it's not good to work in the agriculture field, and playing with mud, plow, FYM, etc. is not a feasible option and moves out from the village in search of employment".

Informant Manoj and Balu believe that without the involvement of the youth in agriculture, it is not possible to develop the agriculture sector. Balu said that government needs to launch the necessary program to attract youth in agriculture. He said that if youth like him willing to engage in agriculture then the government needs to provide the required support so that the agriculture sector will rise.

Despite the farming is labor-oriented, it provides employment opportunities only for three months. In food crops, labor is needed at the time of planting, harvesting, and cleaning whereas very few laborers are needed for vegetable cultivation. Generally, there is an involvement of family members in vegetable cultivation and distribution. A study shows very few people in rural areas of developing countries are unemployed in a strict sense (Perkins et.al., 2013). From nearly full employment during planting and harvesting time to substantially lower levels of employment at other times (Perkins et.al., 2013). Economists say the employment associated with agriculture as underemployment or disguised unemployment.

\section{Gender Role in Agriculture}

Gender roles play a pivotal role in conventional farming. This research finds more contribution of women than men in farming. While interacting with Manoj, Amrit, and Balu, they said that their wife spends more time in the agricultural field. Manoj works in a government office. Amrit works in the fruit and vegetable market. Balu is a high school teacher. In the daytime, they have to go to the office, so their wife and family members look after the farming activities. Informant Ram said he is supported equally by his wife as both of them work together on their farmland. Informant Ganga said she sometimes gets support from her sons but most of the time she alone engages in farmland. Other informant Sita said she works together with her husband in farmland, however, she contributes more to Parma than her husband. The finding shows in absence of male members such as in the case of Manoj, Amrit, and Balu, it is the women who look after all agricultural activities of the house such as planting, harvesting, cleaning, drying, storing, collecting, and selling of agricultural products. This study shows women's contribution is higher than men's in agriculture. Research in Nepal also shows that female engagement in agriculture is higher (Thapa, 2000; Yadhav, 2000). Women contribute more than 50 percent of the production labor and in subsistence crops like maize and millet, women's contribution is as high as 60 to 75 percent in Nepal (Thapa, 2000). In Nepal, women play a vital role in the production of all high value-added commodities, most notably in sericulture, vegetables, ginger, and vegetable seeds (Yadhav, 2000). Globally, women have been contributing enormously to agricultural growth and 
development through their involvement in crop production, horticulture, animal husbandry, fisheries, natural resource management, etc. (Patil \& Babus, 2018).

\section{Income of the Farmers}

The income of the farmers is improving due to higher yields of crops. However, income is not uniform as it depends upon the landholding size and size of the family. Informant Manoj Said, "I can provide education and able to fulfill the needs of my children from the farming income". Ganga said, "The income is sufficient for my family to fulfill the needs of the family. I have not taken other financial supports from others". Another informant Amrit said, " the income from farming is just sufficient but not enough to provide a good education for my children". The study shows the family of Ganga, Sita, and Ram is solely dependent upon income from farming whereas, the family of Amrit, Manoj, and Balu depend upon both income from farming and income from their job. Informant Balu said his income from farming is satisfactory as per his family's contribution to farming. The study shows the income of the farmers is related to the market price of the vegetables. Informant Balu and Ganga said they got a good price for the non-seasonal vegetables. Besides vegetables, Amrit generates money from milk and ghee, and goats. He sells 3 to 4-liter milk in a day and sells 4 to 5 goats in a year. Ganga and Sita both sell milk and ghee. Ganga sells around 5-liter milk every day and Sita sells around 10 liters of milk every day. Sita sells milk at the price of Rs. 80 per liter and earn about NRs. 25000 per month from milk and Ganga sells at the price of Rs. 85 per liter and earn about NRs. 13000 per month. Balu, Manoj, and Ganga believe that their income could be improved if they could shift towards commercial farming. However, they believe that due to limited land size 4 and lack of knowledge on commercial farming they could not shift towards commercial farming.

The increasing labor cost, cost of hiring machines and tractors, cost of pesticides, fertilizers, and hybrid seeds are creating an extra burden to the farmers. Informant Manoj said, he has to invest money in generators every year due to the unavailability of irrigation facilities. He said that he has to change hybrid seeds every two to three years. He finds a challenge on finding labor and said that labor cost is increasing every year. This case is true for the other five informants as well. They believe that labor cost and irrigation cost has been increasing. For buying seeds and fertilizers, they have to allocate money. Despite giving returns from conventional farming, the increasing cost of farming is limiting the income of the farmers. The income of the farmers is varying due to landholding size and family size. Rys-Jurek, (2018) agrees, the production and economic determinants of family farm income depending on the farm's size are indicated, such as utilized agricultural area, crop and livestock production, net investment, and cash flow and inputs.

\section{Market Opportunities}

These informants have easy excess to market so farmers can sell their agriculture productions in the market. Informant Ganga said, she sells vegetables and food crops in different shops in the Sitapaila area and sells Milk to the neighbors. Amrit sells vegetables directly to Kalimati Fruit and Vegetable Center in Kathmandu and sells milk to the neighbors. Balu sells crops and vegetables to different shops of Lamatar and the vegetable market of Lalitpur. Sita sells vegetables in shops near the Lubu area. Manoj sells vegetables and crops in different shops in Jorpati and Mulpani area. Ram

4 They usually have land between 5 ropani to 12 ropani

Nepalese Journal of Development and Rural Studies, Volume 17 
sells vegetables and crops to the middleman. Middleman buys the vegetables and crops from his field and Ram receives money from the middleman. Except for Ram, the other five informants said that there is no presence of a middleman in their area. The study shows four informants Ganga, Sita, Balu, and Manoj sell their vegetables right after harvesting. They said they do not harvest all vegetables at a time, they harvest on regular basis. They took vegetables to market and sell to the local vegetable shops and grocery shops. Sometimes shopkeepers also visit their house to collect vegetables. The harvesting way is the same for Amrit as well, right after harvesting vegetables; he sells to Kalimati Fruit and Vegetable Center. Ram harvests all vegetables at a time and calls to the middleman to collect his vegetables. Because of easy market access, these informants are generating money from selling their agricultural products. Market access is crucial in farming and it is one of the major avenues for improving the livelihood of farmers by selling their agricultural inputs. Markets of agriculture inputs will create agriculture as a sustainable business (Perkins et.al., 2013).

\section{Price of Agricultural Products}

All six informants said the price of the food crops is determined by the market itself. Once they harvest the crop, they store it at home and sell it in the market. Informant Manoj said, "I store paddy in a sack and sell it after five to six months to get a higher price. The price of the stored paddy is higher in the market than the fresh paddy". Informant Ram and Balu also store paddy in sack and Tin and sell it after a few months. The common thing among these informants is that they sell food crops after five to six months of harvesting to get a good price. The price of the crops depends upon the time of the selling and quality of seeds. On the other hand, the prices of the vegetables are not uniform throughout the year. Relatively offseason vegetable gives good price. The practice of growing offseason vegetables in Nepal has served to increase areas under cultivation and production (IBN, 2019). Sometimes farmers do not get their returns due to the fluctuation of vegetable prices in the market. Informant Amrit has just harvested a potato however he is not willing to sell it. He said. "If I sell this potato now I do not get a good price so I prefer to keep it at home". He said due to the fluctuation of the price of vegetables, sometime she doesn't get back his investment. Other informants, Ganga and Sita, also said that price fluctuation in vegetables troubles them to get their investment. Ram sells vegetables directly to a middleman. He said that middleman takes guarantee of taking all vegetables so no matter the price sells vegetables to the middleman. Regarding the price difference of selling vegetables to the middleman, Ram said that "I sold this potato at the price of NRs. 45 per $\mathrm{kg}$ to middleman but when I asked the price of the potato in a local shop, the price of per kg is NRs. 85". This shows the impact of middleman intervention in farming. Research shows middlemen intervention raise price for consumers and the real profit goes to the middlemen who buy up the farm products at almost give away prices and sell at outrageous prices to the consumers (Oguma et. al., 2010). For food crops, farmers do not have to face such problems of middlemen and price fluctuation.

Despite farmers are getting a relatively higher price for the offseason vegetables it has some challenges too. Informant Balu said, "Though the price of the offseason vegetable is higher the un seasonal vegetable farming is expensive because it needs extra precautions like making plastic houses to maintain heat, use of both organic manure and fertilizers and its maintenance cost is higher". Ganga, Amrit, and Ram also do off seasonal vegetable farming and have similar experiences as Balu. However, informant Manoj does seasonable vegetable farming only. During the off-season, he harvests wheat and maize. Sita also said she doesn't dooffseasonal vegetable farming.

Nepalese Journal of Development and Rural Studies, Volume 17 


\section{Farmer's Perception on Conventional Farming}

Farmers identify some challenges in conventional farming. Informant Ram finds new types of diseases and pests in crops. He said that the young generation is not interested in farming. He suggested that to get benefits from farming in the future, the young generation needs to take initiative. As per informant Manoj, one of the good aspects of conventional farming is that one can produce off-seasonal vegetables and multiple crops in the same year. However, he finds difficulty in getting labor at the desired time. He sees the government's role as less effective for promoting farmers and solving the problems of farmers. He is against the random use of land and believes that land should be prioritized based on its soil capacity. Informant Ganga believes that the soil will degrade in near future due to the use of excessive chemical fertilizers. However, she doesn't know the actual solution to it. She believes that new diseases and pests are creating problems for farming. She suggests that farmers should get training and education on different aspects of farming of different crops and livestock. She further believes that if people start to respect their land and farming occupation then farming can well manage their livelihood, income, and employment opportunities. She recommends providing a good subsidy to the farmers.

Informant Amrit believes that conventional farming practices are not going to sustain in the future because of the impact of fertilizers and pesticides on soil and plant. He believes that conventional farming is just good to make money however it is not sufficient as compared to time spent in the field. Though his children are small now, he doesn't believe that his children are also going to involve in agriculture. He believes that if the young generation involves in agriculture then future generations will get enough benefits. He sees the future of organic farming and feels happy that new generations are starting organic farming. He suggests that farmers need to get training and education in agriculture. He seeks supports from the government in terms of subsidies and technical assistance. Informant Balu doesn't see the future of conventional farming and suggests that farming need to be done scientifically rather haphazardly. He claims that organic farming is a better solution for the future and he is trying to shifting towards it. He is happy that newcomers have already started organic farming. He believes that if the government can provide subsidies and good facilities in agriculture then more people will be attracted to agriculture. Informant Sita believes that this farming pattern practice is not sustainable however she does not know what needs to be done for the future. She believes that through proper education and training, things can be changed.

\section{Conclusion}

The conventional farming system is getting popular among Nepalese farmers. It has both benefits and challenges. One major benefit is it increases the yields of agricultural production through the use of fertilizers and compost which ultimately improves the economic status of farmers. Moreover, multiple crops and vegetables can be grown throughout the year. A major challenge of conventional farming is the inadequate knowledge of farmers on the use of fertilizers and pesticides which is giving birth to new diseases on crops and vegetables. Moreover, it is challenged to motivate youths towards farming. To make conventional farming sustainable and to make farmers socio-economically strong, there is a need of shifting towards commercial organic farming. To capacitate farmers, regular training and other skill enhancement program need to be launched. It is suggested that more subsidies and government intervention are needed for improving the farming system that can help in uplifting the socio-economic condition of farmers. 


\section{References}

Adhikari, R. K. (2008). Organic agriculture promotion program progress report. Kathmandu: SECARD Nepal.

Bhatt, D. (2000). Environment and agriculture development in Nepal. In international conference on environment and agriculture (pp. 303-309). Kathmandu: Ecological Society, Nepal.

Central Bureau of Statistics (CBS). (2011). Nepal population and housing census 2011. Kathmandu: Author.

Creswell, J. (2007). Qualitative inquiry and research design: Choosing among five traditions. CA: Sage Publication..

Dahal, K. (2000). Sustainability of Nepalese agriculture: A challenge of our time. Proceedings of the international conference on environment and agriculture ( pp. 310-319).

Department of Agriculture. (2013). Annual report. Lalitpur: Government of Nepal.

Deshar, B. D. (2013). An overview of agricultural degradation in Nepal and its impact on the economy and environment. Global Journal of Economic and Social Development, 1-20.

Gurung, H. (2000). Nepal: Land use in the mountain environment. Proceedings of the International conference on environment and agriculture (pp. 269-280).

IBN (2019). Agriculture sector profile. Kathmandu: Investment Board Nepal.

Jha. P. K. (2000). Environment and agriculture: Trends and perspectives. Proceedings of the international conference on environment and agriculture (pp. 48-62).

Manandhar, G., Adhikary, K. \& Sah, G. (2009). Sustainable agriculture practices and technologies in Nepal. Tech Monitor, 28-37.

Ministry of Agriculture and Cooperative (MoAC). (2008). Nepalese standards of organic agriculture. Kathmandu: Government of Nepal.

Ministry of Finance (MoF). (2019). Economic survey 2018/19. Kathmandu, Nepal: Government of Nepal

Nagaraj et. al., (2006). Economic Impacts of Globalization On Indian Seed Sector and Food Security. Journal of Global Economy,2(2), 91-105. Mumbai, India: Research Centre for Social Sciences.

Nepal Agriculture Research Council (NARC). (2010). NARC's strategic vision for agricultural research (2011-2030). Kathmandu: Author.

Oguoma, O., Nkwocha, V., \& Ibeawuchi, I. (2011). Implications of middlemen in the supply chain of agricultural products. Journal of Agriculture and Social Research (JASR), 10(2). Retrieved from https://doi.org/10.4314/jasr.v10i2.67575

Pasa, R. B. (2017). Technological Interventions in Agriculture Development: A Case from Lele Village of Godavari Municipality, Lalitpur. Nepalese Journal of Development and Rural Studies, 14(1\&2), 86-97.

Patil, B. \& Babus, V. (2018). Role of women in agriculture. International Journal of Applied Research, 4(12), 109-114.

Perkins, D., Radelet, S.,Lindauer, D.,\& Block, S. (2013).Economics of development (7thed.).W.W.Norton \& Company ltd

Pokhrel, M. D. \& Pant, P. K. (2009). Perspectives of organic agriculture and policy concerns in Nepal. The Journal of Agriculture and Environment, 89-99.

Ryś-Jurek, R. (2018). Family farm income and their production and economic determinants according 
to the economic size. International scientific conference 'economic sciences for agribusiness and rural economy', (pp. 21-28). Warsaw.

Sapkota, K. (2011). Sustainable rural development. Kirtipur: Kshitiz Publication:

Shrestha, R. K., (2010). Fertilizer policy development in Nepal. The Journal of Agriculture and Environment, 11, 126-137.

Singh, N., Karki, N. \& Shaha, K. (2000). Status of livestock production in Nepal. Proceedings of the international conference on environment and agriculture (pp. 352-365).

Singh, M. \& Maharjan K. L. (2017). Sustainability of organic farming in Nepal: Crop diversification under organic and conventional farming systems. Springer Nature Singapore Pte Ltd. DOI 10.1007/978-981-10-5619-2_7

Thapa, P. K. (2000). Women and vegetable seed production in the Eastern Hills of Nepal. Proceedings of the international conference on environment and agriculture (pp. 335-351).

Tamang, S., Dhital, M. \& Acharya, U. (2011). Status and scope of organic agriculture in Nepal. Kathmandu, Nepal: Food and Sustainable Agriculture Initiative Forestaction, Nepal.

Tuli, F. (2010). The basis of the distinction between qualitative and the basis of the distinction between qualitative and ontological, epistemological, and methodological perspectives. Ethiop. Journal of Education \& Science, 97-108.

Yadhav, R. (2000). Environment and agriculture plans for Nepal. International conference on environment and agriculture (pp. 281-291). Kathmandu: Ecological Society, Nepal.

Zinati, G. M. (2002). The transition from Conventional to Organic Farming Systems: I. Challenges, Recommendations, and Guidelines for Pest Management. Hort Technology, 12(4), 606-610. Retrieved from https://doi.org/10.21273/HORTTECH.12.4.606 